\title{
Quality of Some Sugar Beet Varieties as Affected by Toshka Region Conditions, Aswan (Egypt)
}

\author{
Reda A. Gomaa ${ }^{1}$; Hesham Z. Tawfeuk ${ }^{1}$ and Ashraf, B. A. EL-Taib ${ }^{2}$ \\ ${ }^{1}$ Food Sci. \& tech. Dept.; Fac. Agriculture and natural resources; Aswan University; Aswan, Egypt \\ ${ }^{2}$ Agronomy Dept. Fac. Agriculture and natural resources; Aswan University; Aswan, Egypt
}

Received: $5 / 3 / 2019$

\begin{abstract}
This investigation was carried out to study the chemical and technological characteristics of three sugar beet varieties namely: Oscar poly, Sultan and Univers which planted under Toshka region conditions at first time in different planting dates for two seasons 2016-2017 and 2017-2018. Samples were analyzed for the following parameters: moisture content, brix, sucrose, reducing sugars, ash, $\mathrm{pH}, \mathrm{K}, \mathrm{Na}, \alpha-\mathrm{N}$, purity of juice and quality of beet sugar. From presented data, the sucrose content (on dry weight basis) ranged from 57.88 to $80.83 \%$, reducing sugars $0.25-1.65 \%$, brix $19.78-32.67 \%$ and ash $0.63-5.77 \%$ (on dry weight basis). The mineral contents were $5.71-8.04,1.56-3.42$ and $1.19-3.63$ milli equivalents $/ 100 \mathrm{~g}$ beet for $\mathrm{K}, \mathrm{Na}$ and $\alpha-\mathrm{N}$, respectively. Juice purity was $67.21-87.91$, sucrose loss in waste ranged from 3.06 to $4.38 \%$. Sucrose recovery on dry weight basis was $47.61-66.49 \%$ and quality of sugar beet was ranged from 78.63 to 83.49 . The obtained results showed that Oscar poly variety had the highest value of purity in the two studied seasons, and sucrose recovery in the first season; while Sultan variety give the highest value of sucrose recovery in the second season.
\end{abstract}

Keywords: Sugar beet, sucrose content, juice purity, sucrose recovery, sucrose loss, beet quality

\section{INTRODUCTION}

Sugar, produced from cane or beet is one of the most widely processed food items. The contribution of cane sugar and beet sugar amount to about 75 and $25 \%$, respectively of annual total world sugar production (Center Sugar Crops, Ministry of Agriculture, 2012).

Sugar industry is one of the oldest industries and strategic goods in Egypt, which contribute about (2.20) million tons from both sugar cane and sugar beet on juice season of (2016) nearly covering $70 \%$ of domestic consumption which is presented about $42.39,57.61 \%$ from sugar cane and sugar beet, respectively. The annual consumption of population from sugar in Egypt is 3.16 million tons so that sugar beet is becoming a growing source of sugar production (Center Sugar Crops, Ministry of Agriculture, 2016). Sugar cane was the only source to produce sugar until the sugar beet was adopted by the Government of Egypt by 1982. Due to land and water scarcity in Egypt at the increase of sugar demand, some efforts were made by the state to increase the cultivated area and productivity of sugar beet source during the last years.

Sugar beet (Beta vulgaris L.) is considered as one of the most important sugar crops, not only for sugar production but also as fodder and organic matter for the soil (Badawy, 1992). However, sugar beet is grown under rather moderate climates, in the northern hemisphere in particular the north and middle Egypt. Also sugar beet has been rather recently introduced in the Egyptian agricultural and industrial activities. There is an intention in the policy of the Egyptian government to expand the cultivation of sugar beet in the new land in the north. Consequently, the numbers of beet factories are increasing. Yet the area planted with sugar beet and the produced white sugar is increased from the period of (1982) to now. Egypt suffers from a negative gap between the production and consumption of sugar. As an attempt to minimize this gap, it was necessary to expand the area planted with sugar beet in the newly reclaimed lands such Toshka region (Ahmed et al., 2017).

Sugar beet composition is important to both the sugar beet farmer and the factory. Sugar (sucrose) and non-sugar (non-sucrose) content determine the quality of the sugar beet where, high sugar and low non-sugar content is desirable. So it is important to evaluate the chemical quality of sugar beet roots in order to evaluate their quality for sugar production. Root yield and technical quality of sugar beet are strongly influenced by weather conditions. The technical quality of sugar beet is essential for economical sugar manufacturing (Asadi, 2007).

The present investigation was carried out to overcome the chemical and technological characters of sugar beet roots cultivated under Toshka region conditions for the first time during different planting dates.

\section{MATERIALS AND METHODS}

Material:

Three sugar beet root varieties namely Oscar poly, Sultan and Univers were obtained from the field of Toshka region (latitude of $22.49^{\circ}$ North, longitude of $28.58^{\circ}$ East), Aswan Governorate, Egyptat different planting dates, 4 October $\left(\mathrm{D}_{1}\right), 18$ October $\left(\mathrm{D}_{2}\right)$ and 4 November $\left(D_{3}\right)$ during 2016-2017 and 2017-2018 working seasons. These verities were harvested at age of 180 days from planting date then the samples were sent to the laboratory of Dakahlia Sugar Company to determine the chemical and technological characteristics.

Methods:

Determination of chemical characteristics:

Moisture content, reducing sugars ash and total soluble solids contents were determined according to the standard methods of AOAC (1990). 
Sucrose content was estimated in samples of sugar beet root using "Saccharometer" according to the method described by AOAC (2005).

The $\mathrm{pH}$ value was measured by using digital bench pH-meter, model pH-526/Sentix - 20/AS$\mathrm{DIN} / \mathrm{SIN} / \mathrm{STH} / 650$ according to procedure of Dakahlia Sugar Company. The $\alpha$-amino $\mathrm{N}, \mathrm{Na}$ and $\mathrm{K}$ contents (meq/100 g beet) was tabulated according to A.O.A.C. (2005).

\section{Determination of technological characteristics:}

Sugar recovery (SR), sugar losses in wastes (SL), juice purity and quality of sugar beetwere determined according to the procedure described by Silin and Silina (1977) and Sapronova et al. (1979) using the following equations:

$$
\begin{aligned}
& \mathrm{SR}=(\mathrm{Pol}-0.29)-0.343(\mathrm{~K}+\mathrm{Na})-\alpha . \mathrm{N}(0.0939) \\
& \mathrm{SL}=0.343(\mathrm{~K}+\mathrm{Na})-\alpha . \mathrm{N}(0.094)+0.29 \\
& \text { Purity }=(\text { Sucrose } \% .100) /(\mathrm{Brix} \%) \\
& \text { Quality }=(\mathrm{SR} .100) / \text { pol. }
\end{aligned}
$$

Where: Pol $=$ Sucrose $\%, \mathrm{~K}=$ Potassium, $\mathrm{Na}=$ Sodium, $\alpha-A . N=$ Alpha-amino nitrogen

\section{Statistical analysis:}

The collected data were statistically analyzed according to Snedecor and Cochran (1981). Treatment means were compared using LSD at 5\% level of probability.

\section{RESULTS AND DISCUSSION}

Sugar beet composition is important to both the sugar beet farmer and the factory. Sugar (sucrose) and non-sugar (non-sucrose) contents determine the quality of the sugar beet where, high sugar and low non-sugar content is desirable. So it is important to evaluate the chemical and technological characteristics of beet juice in order to evaluate the quality of sugar beet for sugar production.

\section{Chemical characteristics of some sugar beet varieties:}

Chemical composition data of sugar beet is given in Table (1). Moisture content: Data in Table (1) exhibited that $\mathrm{D}_{2}$ recorded the highest moisture content in both the first and second season (67.82 and 76.86\%), respectively. Sultan and Univers varieties had higher values of this trait (66.22 and 76.89) in first and second season, respectively. The highest value of this trait was recorded when Sultan variety planted in $\mathrm{D}_{2}$ in first season $(73.47 \%)$ and when Univers variety planted in $\mathrm{D}_{3}(78.66 \%)$ in the second season. The present results are in agreement with the findings of by Abd-Elghaney (2012) who found that moisture content of sugar beet root ranges between 75.69 and $78.68 \%$.

Brix of juice (TSS \%): Data in Table (1) indicated that $\mathrm{D} 1$ and $\mathrm{D}_{2}$ recorded the highest brix \% in the in first and second season (30.49 and $20.89 \%$ ), respectively. Oscar poly and Sultan varieties had higher values of this trait (28.49 and 20.81) in first and second season, respectively. The highest value of this trait was recorded when Sultan variety planted in $\mathrm{D}_{1}$ in first season $(32.67 \%)$ and in $\mathrm{D}_{2}(22.25 \%)$ in the second season. The present results are in agreement with findings of Zalat (1993) and Hozayen (2002). They reported that the TSS of sugar beet juice ranged between 15.54 and $23.60 \%$.

Sucrose content \% (dry weight basis): Data in Table (1) showed that $\mathrm{D}_{3}$ and $\mathrm{D}_{2}$ recorded the highest sucrose content in the first and second season (68.67 and $78.02 \%$ ), respectively. Oscar poly and Sultan varieties had higher values of this trait (68.27 and 78.02) in first and second season, respectively. The highest value of this trait was recorded when Oscar poly variety planted in $\mathrm{D}_{3}$ in first season $(70.97 \%)$. Similar results were recorded by Abou El-Magd et al. (2004) and Asadi (2007).

Reducing sugars \% (on dry weight basis): Data in Table (1) revealed that $D_{1}$ and $D_{2}$ recorded the highest reducing sugars content in the first and second season $(1.57$ and $0.64 \%)$, respectively. Oscar poly and Univers varieties had higher values of this trait (1.42 and 0.64$)$ in first and second season, respectively. The highest value of this trait was recorded when Sultan variety planted in $\mathrm{D}_{1}$ in first season $(1.65 \%)$ and when planted in $\mathrm{D}_{3}(0.83 \%)$ in the second season. Higher reducing sugars values were found in the first season overall varieties. But optimal reducing sugar percent were observed in the second season in different planting date of all varieties. These data are in agreement with those reported by many authors; Abou-Shady (1994) and Abd EL-Mohsen (1996) found that the reducing sugars content ranged between 0.25 and $1.55 \%$ (on dry weight basis).

Ash \%: Data in Table (1) exposed that $\mathrm{D}_{3}$ in the first season recorded the highest ash content $(0.72) . \mathrm{D}_{1}$ and $\mathrm{D}_{3}$ recorded the highest ash $\%$ in the second season $(0.70)$. Oscar poly variety had higher values of this trait (0.71 and 0.74$)$ in first and second season, respectively. From the obtained data, it observed that ash value overall varieties planting in different dates in the first season were higher than that in the second season, high ash percent in sugar beet juice is undesirable because it caused more sugar loss in molasses. The results obtained are in good agreement with Abd-Elghaney (2012) who reported that ash content of beet juice ranged between 0.67 to $1.19 \%$.

$\mathrm{pH}$ value: Data in Table (1) showed that $\mathrm{D}_{2}$ recorded the highest $\mathrm{pH}$ value in the first and second season (6.14 and 6.63), respectively. Oscar poly and Sultan varieties had the highest values of this trait $(6.14$ and 6.63) in first and second season, respectively. The highest value of this trait was recorded when Sultan variety planted in $\mathrm{D}_{2}$ in first season (6.47) and the Oscar poly variety when planted in $\mathrm{D}_{2}(6.68)$ in the second season. These results are in accordance with those of Mathur (1981), who reported that sucrose was more stable at $\mathrm{pH}$ values ranged between 6.5 and 7 during extraction of beet juice. The lower or high $\mathrm{pH}$ values may cause more decomposition of sucrose. 
Table (1): Chemical characteristics of three sugar beet varieties cultivated under Toshka region conditions

\begin{tabular}{|c|c|c|c|c|c|c|c|c|c|c|c|c|c|}
\hline \multirow{2}{*}{ Planting Date } & \multirow{2}{*}{ Varieties } & \multicolumn{6}{|c|}{ Season 2016-2017 } & \multicolumn{6}{|c|}{ Season 2017-2018 } \\
\hline & & $\begin{array}{c}\text { Moisture } \\
\%\end{array}$ & $\begin{array}{c}\text { Brix } \\
\%\end{array}$ & $\begin{array}{c}\text { *Sucrose } \\
\%\end{array}$ & $\begin{array}{l}\text { *Reducing } \\
\text { sugars\% }\end{array}$ & *Ash\% & $\begin{array}{c}\text { pH } \\
\text { value }\end{array}$ & Moisture\% & $\begin{array}{c}\text { Brix } \\
\%\end{array}$ & $*$ Sucrose $\%$ & $\begin{array}{l}\text { *Reducing } \\
\text { sugars\% }\end{array}$ & *Ash\% & $\begin{array}{c}\text { pH } \\
\text { value }\end{array}$ \\
\hline \multirow{3}{*}{ D1 } & Oscar poly & 64.63 & 29.07 & 65.63 & 1.49 & 0.65 & 5.69 & 75.69 & 20.64 & 74.81 & 0.25 & 0.76 & 6.51 \\
\hline & Univers & 63.22 & 29.74 & 64.70 & 1.56 & 0.77 & 4.99 & 76.15 & 20.64 & 73.67 & 0.34 & 0.69 & 6.53 \\
\hline & Sultan & 57.77 & 32.67 & 57.88 & 1.65 & 0.61 & 4.72 & 78.66 & 19.78 & 80.83 & 0.75 & 0.66 & 6.65 \\
\hline \multirow[t]{2}{*}{ Mean } & & 61.87 & 30.49 & 62.74 & 1.57 & 0.68 & 5.13 & 76.83 & 20.35 & 76.44 & 0.45 & 0.70 & 6.56 \\
\hline & Oscar poly & 62.88 & 30.36 & 68.20 & 1.46 & 0.72 & 6.29 & 78.66 & 19.78 & 80.83 & 0.75 & 0.71 & 6.68 \\
\hline \multirow[t]{2}{*}{ D2 } & Univers & 67.13 & 26.55 & 66.08 & 1.29 & 0.59 & 5.65 & 76.15 & 20.64 & 73.67 & 0.34 & 0.63 & 6.53 \\
\hline & Sultan & 73.47 & 22.26 & 69.88 & 0.91 & 0.77 & 6.47 & 75.77 & 22.25 & 79.57 & 0.83 & 0.71 & 6.67 \\
\hline \multirow[t]{2}{*}{ Mean } & & 67.82 & 26.39 & 66.39 & 1.22 & 0.69 & 6.14 & 76.86 & 20.89 & 78.02 & 0.64 & 0.68 & 6.63 \\
\hline & Oscar poly & 69.26 & 26.05 & 70.97 & 1.42 & 0.75 & 6.43 & 75.69 & 20.64 & 74.81 & 0.25 & 0.76 & 6.51 \\
\hline \multirow[t]{2}{*}{ D3 } & Univers & 66.61 & 27.89 & 69.61 & 1.38 & 0.69 & 6.28 & 78.66 & 19.78 & 80.83 & 0.27 & 0.71 & 6.65 \\
\hline & Sultan & 67.43 & 26.37 & 65.61 & 1.57 & 0.73 & 5.49 & 76.15 & 20.40 & 73.67 & 0.34 & 0.63 & 6.57 \\
\hline \multirow[t]{2}{*}{ Mean } & & 67.77 & 26.77 & 68.67 & 1.46 & 0.72 & 6.07 & 76.83 & 20.27 & 76.43 & 0.29 & 0.70 & 6.57 \\
\hline & Oscar poly & 65.59 & 28.49 & 68.27 & 1.42 & 0.71 & 6.14 & 76.68 & 20.53 & 76.82 & 0.42 & 0.74 & 6.23 \\
\hline \multirow[t]{2}{*}{ Mean of var. } & Univers & 65.65 & 28.06 & 66.80 & 1.41 & 0.68 & 5.64 & 76.89 & 20.35 & 76.06 & 0.32 & 0.68 & 6.57 \\
\hline & Sultan & 66.22 & 27.1 & 64.46 & 1.38 & 0.70 & 5.56 & 76.86 & 20.81 & 78.02 & 0.64 & 0.67 & 6.63 \\
\hline \multicolumn{2}{|l|}{ General mean } & 65.82 & 27.88 & 65.93 & 1.42 & 0.70 & 5.78 & 75.84 & 20.50 & 76.96 & 0.46 & 0.69 & 6.59 \\
\hline \multicolumn{2}{|c|}{ LSD $_{0.05}$ for planting date } & 0.01 & 0.32 & 0.26 & 1.38 & 0.02 & 0.06 & 0.01 & 0.01 & 0.04 & 0.06 & 0.02 & 0.003 \\
\hline \multicolumn{2}{|c|}{ LSD $_{0.05}$ for var. } & 0.004 & 0.15 & 0.14 & 1.03 & 0.01 & 0.02 & 0.004 & 0.06 & 0.04 & 0.12 & 0.01 & 0.002 \\
\hline \multicolumn{2}{|c|}{ LSD $_{0.05}$ for plant. date X Var. } & 0.01 & 0.26 & 0.24 & 1.79 & 0.02 & 0.04 & 0.01 & 0.11 & 0.07 & 0.20 & 0.02 & 0.003 \\
\hline
\end{tabular}

* Determined on dry weight basis 
Technological characteristics of three sugar beet varieties:

Sucrose recovery depended on some factors such as sucrose, potassium $(\mathrm{K})$ and $\alpha$-amino $\mathrm{N}$ content. It has positive correlation with sucrose content and negative correlation with $\mathrm{Na}, \mathrm{K}$ and $\alpha-\mathrm{N}$ content of sugar beet juice. Data in Table (2) displayed that $\mathrm{D}_{3}$ and $\mathrm{D}_{2}$ recorded the highest Sucrose recovery on dry weight basis \% (S.R) in the first and second season (56.59 and 63.02), respectively. Oscar poly variety had higher values of this trait (56.46 and 63.44) in first and second season, respectively. The highest value of this trait was recorded when Sultan variety planted in $\mathrm{D}_{2}$ in the first season $(59.20 \%)$. These findings are in agreement with Gomaa (2009).

Data in Table (2) showed that $\mathrm{D}_{1}$ and $\mathrm{D}_{2}$ recorded the highest Sucrose loss (S.L) present in the first and second season (4.24 and $3.37 \%$ ), respectively. Oscar poly variety had higher values of this trait $(4.03 \%)$ in first season, and Sulatan variety recorded the highest values in the second season $(3.37 \%)$. The highest value of this trait was recorded when Sultan variety planted in $\mathrm{D}_{1}$ in the first season $(4.38 \%)$ and in $\mathrm{D}_{2}(3.79 \%)$ in the second season. These findings are agreement with results reported by Gomaa (2009) who reported that the losses of sucrose in wastes were ranged from 3.06 to $4.12 \%$ in the beet juice. From data in Table (2), it could be said that by decrease the sucrose loss in wastes, the sugar produced (sucrose recovery) as white sugar increase.

The juice purity (J.P \%) of sugar beet juice is defined as the ratio of sucrose to total soluble solids (brix), as a percentage. Data in Table (2) illustrated that $\mathrm{D}_{2}$ and $\mathrm{D}_{1}$ recorded the highest juice purity in the first and second season (82.99 and $87.08 \%$ ), respectively. Oscar poly and Sultan varieties had the highest values of this trait $(82.71$ and $86.66 \%)$ in first and second season, respectively. The highest value of this trait was recorded when Sultan variety planted in $\mathrm{D}_{2}$ in the first season $(85.20 \%)$ and the Oscar poly variety when planted in $\mathrm{D}_{1}$ $(87.91 \%)$ in the second season. It can be said that, the main goal of the sugar factory is to separate non-sugar from sugar to improve the beet juice purity to the extent that sugar with $100 \%$ purity is produced. Also, by increase the purity of beet juice would make sugar beet processing much faster and easier. These results were supported by (Asadi, 2007; Zohri et al., 2014) who reported that the purity of beet juice usually ranged from 85 to $88 \%$ in atypical washed beet (beet without tare).

The quality of sugar beet (Q) decrease in the case of arising alkaline ( $\mathrm{K}$ and $\mathrm{Na}$ content) and nitrogen content. Data in Table (2) disclosed that $\mathrm{D}_{3}$ and $\mathrm{D}_{1}$ recorded the highest quality of sugar beet in the first and second season (82.41 and $82.22 \%$ ), respectively. Oscar poly variety had higher values of this trait (82.80 and $82.55 \%)$ in the first and second season, respectively. The highest value of this trait was recorded when Univers variety planted in $\mathrm{D}_{3}$ in the first season $(83.49 \%)$ and the Oscar poly variety when planted in $D_{1}$ $(82.95 \%)$ in the second season. The results are in agreement also with those reported by Ramazan (2002) and Refay (2010).

Data in Table (2) revealed that $D_{1}$ and $D_{2}$ recorded the highest Potassium $(\mathrm{K})$ content in the first and second season (7.74 and 6.46\%), respectively. Univers and Sultan varieties had higher values of this trait $(7.58$ and $6.46 \%)$ in first and second season, respectively. The highest value of this trait was recorded when Sultan variety planted in $D_{1}$ in first season $(8.04 \%)$ and the same variety when planted in $\mathrm{D}_{2}$ $(7.05 \%)$ in the second season. These are in agreement with those reported by El-Geddawi (1988).

Data in Table (2) displayed that $\mathrm{D}_{1}$ and $\mathrm{D}_{2}$ recorded the highest Sodium content $(\mathrm{Na})$ in the first and second season (2.55 and 2.28\%), respectively. Oscar poly and Sultan varieties had higher values of this trait $(2.51$ and $2.31 \%)$ in first and second season, respectively. The highest value of this traits was recorded when Univers variety planted in $D_{1}$ in first season (2.92) and when Sultan variety planted in $\mathrm{D}_{2}$ $(3.42 \%)$ in the second season these results are not in agreement with finding of Abou- Shady (1994).

Alpha amino nitrogen $(\alpha-n)$ in the beet roots decreases refined sucrose production and have deleterious effect on juice purification and sucrose crystallization. Since this compound react with carbonyl compounds in the juice to form Maillard products, such products decrease crystallization rate and discoloration the product that raises the production cost of white sucrose production (Ram, 1978). Data in Table (2) revealed that $D_{3}$ and $D_{2}$ recorded the highest $\alpha$ amino nitrogen in the first and second season (2.70and 3.75\%), respectively. Oscar poly and Sultan varieties had higher values of this trait (3.16 and $1.82 \%)$ in first and second season, respectively. The highest value of this traits was recorded when Oscar poly variety planted in $\mathrm{D}_{2}$ in first season $(3.63 \%)$ and the Sultan variety when planted in $\mathrm{D}_{2}(2.56 \%)$ in the second season.

\section{CONCLUSION}

From this investigation it can observed that Oscar poly variety recorded the highest value of purity in the first and second season and sucrose recovery in the first season. While Sultan variety give the highest value of sucrose recovery in the second season. Generally it can be recommended to planting Oscar poly variety in $\mathrm{D}_{3}$, Sultan variety in $D_{2}$ and Univers variety in $D_{2}$ because it's give high juice purity and sucrose recovery in this planting date.

\section{REFERENCES}

AOAC (1990). "Official Methods of Analysis Association of Official Analytical Chemists" Washington D.C. USA.

AOAC (2005). Association of Official Analytical Chemists."Official Methods of Analysis", $16^{\text {th }}$ ed. Inter. Washington, D.C, USA.

Abd El-Mohsen, N. E. (1996). Chemical and technological studies on sugar beet. Egypt. J. Food Sci., 24(1): 1-14. 
Table (2): Technological characteristics of three sugar beet varieties cultivated under Toshka region conditions

\begin{tabular}{|c|c|c|c|c|c|c|c|c|c|c|c|c|c|c|c|}
\hline \multirow[b]{2}{*}{ Planting Date } & \multirow{2}{*}{ Varieties } & \multicolumn{7}{|c|}{ Season 2016-2017 } & \multicolumn{7}{|c|}{ Season 2017-2018 } \\
\hline & & $\mathbf{K}$ & $\mathbf{N a}$ & $\alpha-\mathbf{N}$ & J.P\% & S.L\% & $\begin{array}{l}\text { S.R on dry } \\
\text { weight } \%\end{array}$ & $\mathbf{Q}$ & $\mathbf{K}$ & $\mathbf{N a}$ & $\alpha-\mathbf{N}$ & J.P\% & S.L\% & $\begin{array}{l}\text { S.R on dry } \\
\text { weight } \%\end{array}$ & $\mathbf{Q}$ \\
\hline \multirow{3}{*}{ D1 } & Oscar poly & 7.61 & 2.67 & 3.01 & 81.28 & 4.09 & 55.31 & 82.70 & 5.71 & 1.97 & 1.75 & 87.91 & 3.09 & 61.91 & 82.95 \\
\hline & Univers & 7.85 & 2.92 & 2.61 & 80.17 & 4.26 & 53.22 & 82.31 & 6.36 & 1.65 & 1.71 & 86.13 & 3.26 & 60.00 & 81.46 \\
\hline & Sultan & 8.04 & 2.06 & 2.92 & 74.97 & 4.38 & 47.61 & 82.16 & 5.78 & 1.87 & 1.19 & 87.21 & 3.06 & 66.49 & 82.25 \\
\hline Mean & & 7.74 & 2.55 & 2.85 & 78.81 & 4.24 & 52.08 & 82.18 & 5.95 & 1.83 & 1.5 & 87.08 & 3.14 & 62.8 & 82.22 \\
\hline \multirow{3}{*}{ D2 } & Oscar poly & 7.77 & 2.46 & 3.63 & 82.44 & 4.11 & 56.01 & 83.46 & 5.78 & 1.87 & 1.19 & 87.21 & 3.06 & 66.49 & 82.26 \\
\hline & Univers & 7.51 & 2.44 & 2.35 & 81.32 & 3.87 & 54.21 & 81.80 & 6.56 & 1.56 & 1.71 & 86.13 & 3.26 & 60.00 & 81.95 \\
\hline & Sultan & 6.97 & 2.13 & 1.98 & 85.20 & 3.62 & 59.20 & 81.02 & 7.05 & 3.42 & 2.56 & 86.65 & 3.79 & 62.57 & 78.63 \\
\hline Mean & & 7.42 & 2.34 & 2.65 & 82.99 & 3.87 & 56.47 & 82.09 & 6.46 & 2.28 & 3.75 & 86.66 & 3.37 & 63.02 & 80.95 \\
\hline \multirow{3}{*}{ D3 } & Oscar poly & 7.29 & 2.40 & 2.85 & 83.88 & 3.88 & 58.06 & 82.25 & 5.71 & 1.97 & 1.75 & 78.89 & 3.09 & 61.91 & 82.45 \\
\hline & Univers & 7.38 & 2.05 & 2.96 & 83.61 & 3.84 & 58.27 & 83.49 & 5.78 & 1.87 & 1.19 & 67.21 & 3.06 & 66.49 & 82.26 \\
\hline & Sultan & 7.42 & 2.65 & 2.28 & 81.09 & 3.99 & 53.44 & 81.49 & 6.56 & 1.65 & 1.71 & 86.13 & 3.26 & 60.00 & 81.46 \\
\hline Mean & & 7.36 & 2.37 & 2.70 & 82.86 & 3.90 & 56.59 & 82.41 & 6.02 & 1.83 & 1.55 & 77.41 & 3.14 & 62.80 & 82.05 \\
\hline \multirow{3}{*}{ Mean of var. } & Oscar poly & 7.56 & 2.51 & 3.16 & 82.71 & 4.03 & 56.46 & 82.80 & 5.73 & 1.94 & 1.56 & 84.67 & 3.08 & 63.44 & 82.55 \\
\hline & Univers & 7.58 & 2.47 & 2.64 & 81.70 & 3.32 & 55.38 & 82.53 & 6.23 & 1.69 & 1.54 & 79.82 & 3.19 & 62.16 & 81.89 \\
\hline & Sultan & 7.48 & 2.28 & 2.39 & 80.40 & 4.00 & 53.42 & 81.56 & 6.46 & 2.31 & 1.82 & 86.66 & 3.37 & 63.02 & 80.78 \\
\hline \multicolumn{2}{|l|}{ General mean } & 7.51 & 2.42 & 2.73 & 81.55 & 4.00 & 55.05 & 82.22 & 6.14 & 1.98 & 2.27 & 83.72 & 3.22 & 62.87 & 81.74 \\
\hline \multicolumn{2}{|c|}{ LSD $_{0.05}$ for planting date } & 0.03 & 0.01 & 0.01 & 0.16 & 0.02 & 0.37 & 0.002 & 0.03 & 0.03 & 0.01 & 0.39 & 0.24 & 0.14 & 0.03 \\
\hline \multicolumn{2}{|l|}{ LSD $_{0.05}$ for var. } & 0.05 & 0.02 & 0.02 & 0.07 & 0.01 & 0.24 & 0.02 & 0.03 & 0.04 & 0.02 & 0.17 & 0.19 & 0.17 & 0.03 \\
\hline \multicolumn{2}{|c|}{ LSD $_{0.05}$ for plant. date X Var. } & 0.03 & 0.04 & 0.04 & 0.13 & 0.02 & 0.42 & 0.03 & 0.05 & 0.07 & 0.03 & 0.29 & 0.32 & 0.30 & 0.05 \\
\hline
\end{tabular}


Abd-Elghaney I. M. H. (2012). Study of the factors affecting non-sugar removal of the beet end. M.Sc. Thesis, Sugar Tech. Research Inst., Assiut Univ., Egypt.

Abou ELMagd, B. M., S. Youssif and O. A. Nariman (2004). Effect of some chemical treatments on the chemical quality and storability of sugar beet roots after harvest. Egypt. J. APP. Sci., 19(11): $263-277$.

Abou- Shady, K. A. (1994). Chemical and Technological Studies on Sugar Beet and Wastes. M. Sc. Thesis, Fac. of Agric., Al Azhar Univ., Egypt.

Ahmed, A. Z., A. O. Awadalla and Sakina R. Abazid (2017). Possibility of sugar beet production in Toshka region. J. Plant Production, Mansoura Univ., 8(12): 1409-1415.

Asadi, M. (2007). Beet-Sugar Handbook. John Wiley and Sons, Inc., Hoboken, New Jersey. pp. 550 -615 .

Badawy, E. M. (1992). Biochemical studies on sugar metabolism in sugar beet plants. PhD Thesis, Fac. of Agric., Menoufiya Univ., Egypt.

Center Sugar Crops, Ministry of Agriculture, January (2012).

Center Sugar Crops, Ministry of Agriculture, January (2016).

El-Geddawi, I. H. (1988). Deterioration of sugar crops.1- Sugar beet deterioration. Alexandria Science Exchange, 9(3): 385-405.

Gomaa, S. (2009). Effect of calcium hydroxide and acetic acid on the rat of deterioration and dextran formation during sugar beet storage. M.Sc. Thesis, Sugar Tech. Research Inst., Assiut Univ., Egypt.
Hozayen, A. M. A. (2002). Technological and chemical studies on sugar beet roots. M.Sc. Thesis, Fac. of Agric., Ain Shams Univ., Egypt.

Mathur, R. B. (1981). Handbook of Cane Sugar Technology. Oxford I. B. H. Publishing Co.

Ram, B. L. (1978). Handbook of Cane Sugar Technology. Publish by Mahen Primalani, Oxford \& IBH Publishing Co; Delhi 11001 India. p. 38- 39.

Ramazan, C. (2002). Root yield and quality of sugar beet in relation to sowing date, plant population and harvesting date interactions. Turk. J. Agric., 26: 133-139.

Sapronova, A., A. Jofhman and V. Loseava (1979). General Technology of Sugar Substances. Bischedya Bromifhenosc. Pub, Moscow, 464 p.

Silin, P. M. and N. D. Silina (1977). Chemical Control in Sugar Technology. Food Technology Pub, USSR, pp. 120-126.

Snedecor, G.W. and W. G. Cochran (1981). Statistical Methods. Oxford and I. B. H. Publishing Co. $6^{\text {th }}$ Ed., pp. 299-310.

Refay, Y. A. (2010). Root yield and quality traits of three sugar beets (Beta vulgaris L.).World Journal of Agricultural Sciences, 6(5): 589594.

Zalat, S. S. (1993). Effect of some cultural practices on sugar beet. Ph.D. Thesis, Fac. of Agric. Zagazig Univ., Egypt.

Zohri, A. A., O. A. El Shahaby, A. M. Mamdouh, E. H. El Sayed and M. Y. Mohammed (2014). Determination of sucrose losses in beet sugar manufacturing at Dakahlia sugar company, Egypt. Egyptian Sugar Journal, 7: 28-50.

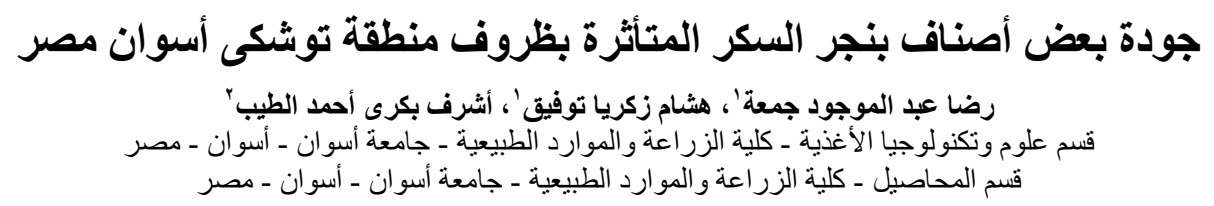

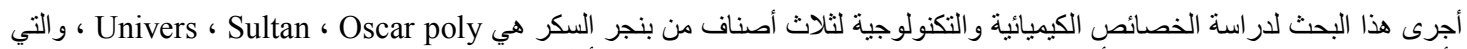

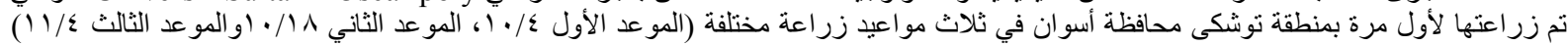

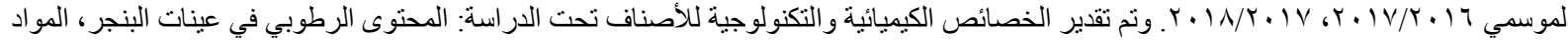

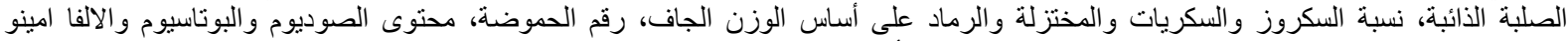

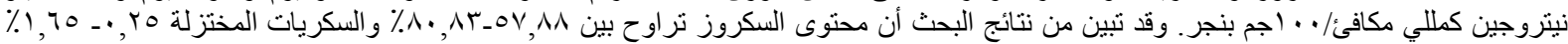

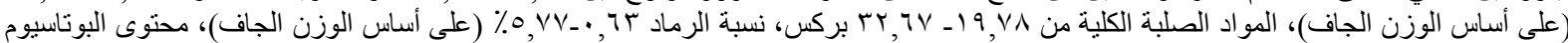

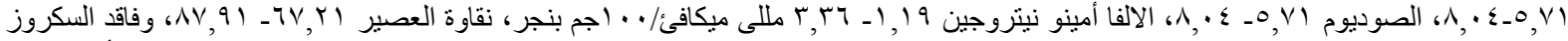

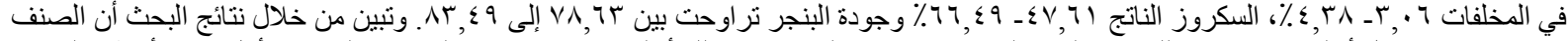

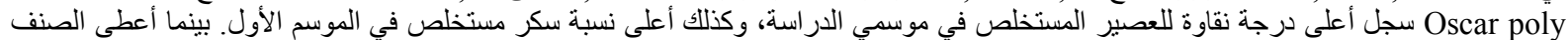
Sultan 